\title{
A IMPORTANCIA DO ENSINO DE FILOSOFIA NAS ESCOLAS DO ENSINO MÉDIO
}

Esta dissertação traz como enfoque práticas pedagógicas alternativas no ensino de Filosofia. A concepção de Filosofia difundida na educação escolar brasileira historicamente esteve ligada a saberes abstratos e racionalistas, ligados à formação das elites. Suas bases escolásticas desde o Brasil Colônia a desvincularam de características contextualizadas de um ensino voltado à realidade vivencial, afastando-a de possibilidades de reflexão e problematização (RODRIGUES, 2012). Há no Brasil, ainda uma carência de professores formados em Filosofia para o provimento da docência na disciplina no ensino médio mesmo após o Parecer de 2006 (CNE/CEB nº 38/2006), que imputou à disciplina o status da obrigatoriedade.

Contudo, nota-se que o ensino desta disciplina se mostra cada vez mais desafiador e assim como preconiza os Parâmetros Nacionais Curriculares. Ao considerar como "princípios gerais do Ensino Médio" os delineados na lei (basicamente na LDB), o espírito da proposta de ensino desenvolvida na parte dos PCNEM, dedicada à Filosofia, pretende parecer coerente com a concepção delineada nos textos que compõem as Bases Legais. Ainda que essa coerência repouse sobre a ambigüidade fundamental, já apontada, de o texto da lei (tanto na LDB, Lei 9.349/96, quanto nas DCNEM) não assegurar a oferta da Filosofia enquanto disciplina obrigatória do Ensino Médio, a parte dos PCNEM, dedicada à Filosofia, concebe seu ensino de modo eminentemente disciplinar. Na verdade, a proposta de ensino de conhecimentos de Filosofia, desenvolvida nos Parâmetros, é apenas parcialmente coerente com a concepção delineada nos textos que compõem suas bases. Não há, contudo, conflito explícito entre as DCNEM, os PCNEM e a LDB, mas sim uma ambigüidade fundamental no espírito inteiro do projeto de Filosofia para o Ensino Médio. Essa imprecisão reflete-se na dupla orientação dos documentos oficiais. Enquanto a LDB e as DCNEM não asseguram a oferta de Filosofia como disciplina obrigatória, embora o facultem, os Parâmetros não lhe oferecem outro tratamento que não o eminentemente disciplinar.

O significado da palavra "filosofia" é derivado de dois vocábulos gregos que tem o sentido de "amando a sabedoria". Este era o conceito que havia na mente dos antigos, logo o papel primário da filosofia é moral, virtuoso e ético. A definição mais 
apropriada de filosofia poderá ser dada pelos próprios filósofos, ainda que seja divergente e em parte incoerente, até porque um dos próprios papéis do filósofo é descobrir as verdades acerca da filosofia. A filosofia analítica, por exemplo, tem como preocupação central o estudo analítico dos conceitos. Assim, ele deve ter como intuito definir os termos filosóficos e científicos, e esclarecer a linguagem das idéias. A filosofia especulativa por sua vez está preocupada com a sintetização dos resultados da pesquisa dos conceitos, com o fito de formar um conceito compreensivo e integrado da realidade (NORMA; FEINBERG, 1996).

Ao discutir, a partir de alguns referenciais teóricos e da experiência pessoal, a importância de se promover uma educação pensada e organizada, levando em consideração que as complexas situações criadas pelos estudantes na rotina escolar em vista de seus conhecimentos, exigências e necessidades são de tamanha complexidade, que dificilmente qualquer tarefa ou disciplina isolada tem reais e seguras condições de docência didática e pedagógica. Uma pesquisa evidenciou que, independentemente dos desafios e da complexidade, cabe ao docente a tarefa primordial de conduzir correta e equilibradamente o trabalho didático e pedagógico na sala de aula (MENDES, 2014).

No ensino de Filosofia, tão importante quanto o processo de filosofar é fazer que os alunos encontrem sentido no conteúdo filosófico a eles proposto, pois dessa construção depende o sucesso da aprendizagem (MENDES, 2014).

A fim de abordar esta temática foi feita uma revisão na literatura, cujo método é pesquisa bibliográfica, que segundo Gil (2002), “é considerada o primeiro passo de qualquer pesquisa científica, pois recolhe e seleciona conhecimentos prévios e informações acerca de um problema ou hipótese, já organizado e trabalhado por outro autor, colocando o pesquisador em contato direto com materiais e informações que já foram escritos anteriormente sobre determinado assunto". Toda hipótese deve indicar uma situação possível de ser admitida cientificamente, deve ser clara e simples, deve restringir-se a variáveis do problema de pesquisa e dever ser passível de verificação, cujo enunciado não deve entrar em contradição com o conhecimento científico mais amplo e deve ser explicativa, isto é, deve estar articulada com o problema de pesquisa, servindo como explicação deste (SAMPIERI, COLLADO e LÚCIO, 2013).

Quanto ao enfoque será o qualitativo (SAMPIERI, COLLADO e LÚCIO, 2013). De acordo com Bogdan e Biklen (1982), a pesquisa qualitativa define-se de acordo com cinco características básicas: 
1) A pesquisa qualitativa tem o ambiente natural como sua fonte direta de dados e o pesquisador como seu principal instrumento;

2) Os dados coletados são predominantemente descritivos;

3) $\mathrm{O}$ interesse do investigador é muito maior com o processo do que com o produto;

4) Os dados são analisados de forma indutiva;

5) O significado que diferentes pessoas dão às suas vidas é de grande importância para o pesquisador. Como o presente trabalho teve por objeto de estudo uma única turma da escola em questão, ele se "destaca por se constituir numa unidade dentro de um sistema mais amplo" (LÜDKE e ANDRÉ, 1986, p.17), tendo por interesse estudar o que as aulas de química da turma investigada têm de único, de particular, levando-se, portanto, a considerá-lo um estudo de caso.

Além da pesquisa bibliográfica, entrevista e observação em uma instituição de ensino foi feita também uma análise documental que permitiu: 1) um melhor embasamento sobre o funcionamento da Instituição a partir da análise do Projeto de Desenvolvimento Institucional; 2) uma melhor apreensão sobre a prática pedagógica do Professor a partir de avaliações, trabalhos em grupo, planejamento anual de conteúdo, livro didático ${ }^{1}$, entre outros.

Foi realizada a observação das aulas da Professor Ronaldo Pinheiro em uma turma do $3^{\circ}$ ano do Ensino Médio ${ }^{2}$ na referida Escola, a fim de detectar na prática pedagógica do professor quais metodologias e os recursos utilizados por ele durante as aulas e verificar se os Parâmetros Curriculares Nacionais e a Base Nacional Comum Curricular influenciavam no planejamento de suas aulas (em caso afirmativo, como?). $\mathrm{Ou}$ ainda, quais critérios eram por ele utilizados para atingir o principal objetivo educacional: a aprendizagem dos alunos.

A observação se deu a partir de anotações dos conteúdos a respeito do livro didático adotado, da atitude pedagógica do professor perante os alunos, dentre outras coisas igualmente relevantes, com uso de tecnologias e as metodologias inovadoras.

\footnotetext{
${ }^{1}$ É importante destacar que o livro didático é uma ferramenta de ensino amplamente utilizada nas escolas, sendo um gênero constituído de outros gêneros, formando sua própria identidade por meio dessa miscelânea; não deve ser considerado um simples suporte, pois não é um conjunto de textos sem autoria e estilo (BUNZEN, 2005).

${ }^{2} \mathrm{O}$ ensino médio deverá permitir aquisição de competências relacionadas ao pleno exercício da cidadania e da inserção produtiva: autoaprendizagem; percepção da dinâmica social e capacidade para nela intervir; compreensão dos processos produtivos; capacidade de observar, interpretar e tomar decisões; domínio de aptidões básicas de linguagens, comunicação, abstração; habilidades para incorporar valores éticos de solidariedade, cooperação e respeito às individualidades (COLOMBO, 2005, p. 53).
} 
Este trabalho foi realizado de 10 maio a 17 de outubro de 2018, totalizando 30 h/a, período que corresponde a dois bimestres letivos. A carga horária de Filosofia no Ensino Médio nesta instituição restringe-se a 2 h/a semanais. Ainda assim, apesar do curto tempo para o desenvolvimento de um conteúdo programático extenso, a professora utiliza uma metodologia bastante diversificada.

\author{
AUTOR: \\ CARLOS ANTONIO CARVALHO DA SILVA \\ MESTRE EM CIENCIAS DA EDUCAÇAO.
}

